\title{
IMPROVING THE STUDENTS' ABILITY TO WRITE DESCRIPTIVE PARAGRAPH THROUGH DRAW LABEL CAPTION (DLC) TECHNIQUE
}

\author{
Meningkatkan Kemampuan Siswa Dalam Menulis Paragraf Deskiptif Melalui Teknik \\ Draw Label Caption (DCL)
}

Ika Sastrawati

English Education Department, Faculty of Teacher Training and Education Muhammadiyah University of Makassar

\begin{abstract}
ABTRACT
This research aimed at find out the improvement of the students' writing descriptive paragraph viewed from its content with unity and completeness, language use dealing with tense and preposition through DLC Technique at the eighth grade of MTs.Muhammadiyah Tongko. The technique of this research was a classroom action research (CAR) which was conducted in two cycles in which every cycle consisted of four meetings. The instrument of the research was observation sheet and writing test indicated that the students have high score in writing achievement. The location of this research was taken at the eighth grade of MTs.Muhammadiyah Tongko with a number of the subject were 30 students. The research findings indicated that the application of DLC Technique was significant in improving the students' writing descriptive paragraph viewed from content and language use. It was proved by the mean score of cycle I was 63.99. It was classified as fair then improved to be 75.50. It was classified as good in cycle II. They are higher than the mean score of diagnostic test namely 50.99 that classified as poor. Therefore there was the improvement of the students' writing descriptive paragraph viewed from its content with unity and completeness, and language use dealing with tense and preposition.
\end{abstract}

Keywords: descriptive paragraph, draw label caption

One of the integrated skills that should be mastered by the students is writing. Writing is one of activities that the students do most in their study. So, it is important that they have to know how to write correctly. According to Byrne (1995: 5) that writing is a process of expressing feeling, idea and thought from a writer to the readers. He also explains that each writer should have several techniques and should be knowledgeable to make their writing interesting. In writing skill, the students can write simple sentences or short paragraphs, but it is not easy for students do in writing.

In fact, teaching writing activities at the school can not improve the ability of the students. Writing is neglected by teacher and students because they think that writing is very difficult and boring subject in teaching learning process. Based on the previous finding problems above, it is necessary to provide various 
activities through a variety of technique or method for the students, so that they can write well.

Using DLC Technique is one of the alternatives for the teacher in designing writing materials for the students. DLC Technique is a technique or method to provide inspiration for the students that will motivate them to express themselves creatively through writing. According to Steve $(2003 ; 45)$ that DLC Technique is the both a lesson plan and pre-writing technique that can help the students before writing a functional story or a personal narrative. It can olso be used to introduce new vocabularthe basic technique is those the students draw a picture,then label everything in their picture and then give an overall caption or summary of what is happening in the picture. It can stimulates the students skill in writing by working drawing picture until arrange some sentences into a good descriptive paragraph.

Based on previous studies, the researcher is interested in conducting classroom action research by applying DLC Technique in improving students' writing ability. Classroom action research is conducted in this research as Kemmis and McTaggart in Adilu (2011: 5) suggests that teachers have to use action research with goal of solving a specific problem in their classrooms.

\section{Definition of Draw Label Caption (DLC)}

Below is the defenition about the draw- label-caption technique based on some sources:

\section{a. Draw}

According to Bull (2008: 131), the word Draw is:

1. To make pictures, or a picture of something, with a pen, pencil or chalk (but not paint).

2. To move something/ somebody by pulling it or them gently.

3. To pull a vehicle such as carriage.

Moreover Peha (2003: 47) states that draw is making a quick pencil sketch of your scene. Based on the explanation above, it can be inferred that draw is the activity make a picture with using a tool (s) with the certain object and purpose. 
And also explain that "drawing for writing is a little different than normal drawing because it has a purpose."

\section{b. Label}

Etymologically, the word "label" have some meaning according to Bull (2008: 239) as follows:

1. A piece of paper, clothes, etc. that is attached to something and gives information about it.

2. A word or phrase that is used to describe somebody/something in a way that seems too general, unfair or not correct.

In addition, Peha (2003: 47) defines label as "create one or two word text label for each item in your drawing." From the quotation above, the writer assumes that label is one word or more that can be used to give a name for an object.

\section{c. Caption}

Bull (2008: 57), the word caption is defined as "words that are printed underneath a picture, cartoon, etc. that explain or describe it. Based on the quotation above, it can be inferred that caption is a phrase that can be the main or topic of the paragraph. Julie Bumgardner, states that Draw Label Caption technique is the technique, kinds draw a picture representing their topic, label different parts of the picture, and write a short caption undernearth.

Peha (2003:47) explains "drawing for writing is a little different than normal drawing because it has a purpose". Furthermore, Peha (2003:47) makes a conclusion that

By using this technique can be founded the general, specific word and also about the topic of the sentence in a paragraph. The students can draw from their own mind that relate with the topic. When the students take a few minutes to sketch a quick picture, the students give themselves a chance to focus on the students' topic and can make their writing richer and more detailed. 


\section{The Procedure of Draw Label Caption Technique}

According Peha (2003:47-48), DLC Technique has some process that should be done by the students before they write a paragraph. The students can follow the step process in this technique. Below is the explanation about the steps process of this technique.

There are steps to apply DLC technique to achieve the purpose in writing process like:

1. Draw; make a quick pencil sketch of the scene. This is a rough sketch: we also use outlines only, stick people are encouraged. Try to include as many little details as we can. Drawing a picture makes us more familiar with the scene and helps us to think of the things to write about. Drawing helps us visualize details which helps to find the words which help the readers create the same picture in their minds that we are creating. (Peha, 2003:47-48). Have the student to draw a picture. The most important thing that they have to do are they should show the main action, the background or context and where thing related each other.

Walton (2007: online), writing stories or narratives is much easier when the students have a picture.

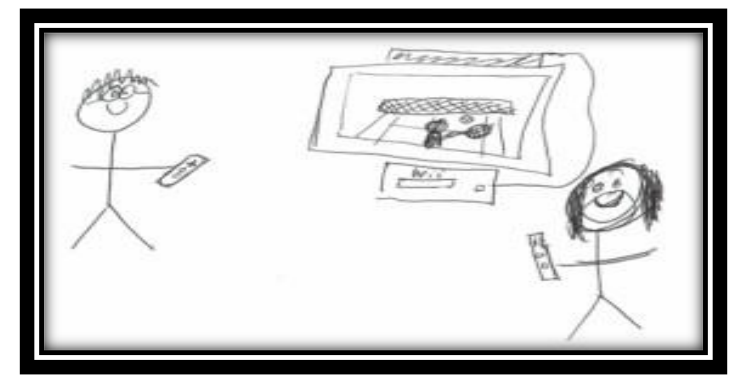

Figure 1: The example of drawing a picture that will be the main idea.

(Peha, 2003:49)

2. Label; create one or two word text label for each item in your drawing. Label everything we can think of, even different parts of things (Peha, 2003:47-48). Furthermore Walton (2007), label as many words as possible around the picture. As example of label below: 


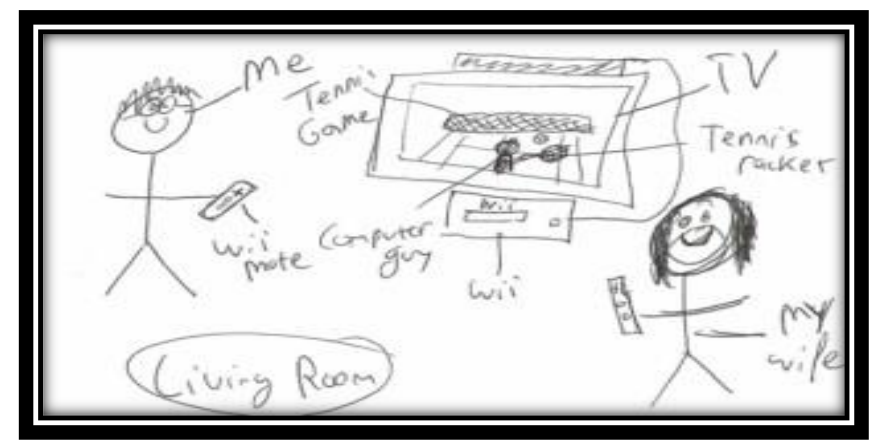

Figure 2: The example of Label about the picture. (Peha, 2003: 49)

3. Caption; write a single sentence underneath the picture that tells what is happening. This can be a very simple sentence or something more complicated if we are up for it (Peha, 2003:47-48). Have the student to write descriptions of everything in their picture. Walton (2007: online) explain that" encourage them to think about colors, smells, texture, materials.

Peha (2003:49-50) explain the example of caption after give label (figure2) on the picture of figure 1, as follows:

Living room: My living room is large. My living room is yellow. There is a sofa and 2 chairs in there. The living room is the biggest room in the house. Me: I'm playing Wii Tennis with my wife. It is fun. We play against each other. We like to win. Wii Tennis: The game is funny. The men have no arms. They are cartoon men. You can jump high. It is hard to play. Wii Mote: When you move it, your tennis racket moves. It feels like a real game. The Wii Remote is white. My wife: She is tall and thin. She likes to win. But I am better than she is.

\section{Description}

The students can make revision for their writing to complete scene or story like the example below:

Sometimes I like to play tennis in my living room. My living room is large. My living room is yellow. There is a sofa and 2 chairs in there. The living room is the biggest room in the house. I play Tennis with my wife. It is fun. We play against each other. We like to win. The game is funny. The man has no arms. They are cartoon men. You can 
jump high. It is hard to play. When you move it, your tennis racket move. It fell like a real game. The remote is white (Peha, 2003:49-50).

From the explanation of steps of DLC Technique above, the researcher can conclude that this strategy have three steps, namely: first, draw a picture that will be the main idea of their story, second is label as many words as possible around the picture, and then write a caption in the bottom of the picture to go along with the picture (start with a phrase), after that make a sentence from the label and the last each sentence can be included into a descriptive paragraph.

Moreover, Steve Peha (2003: 51) also suggests some tips to develop the students writing ability on the DLC Technique, namely:

1. The students should not be shy about drawing. Drawing can really help in preparation for writing, will be much more focus, will have better command of the details and while you're drawing, will spend several minutes thinking about what you want to say.

2. Really get into the labeling. It has already explained about how each label can be turned into a detail on the students' piece, and how each detail can then be turned into a sentence or two.

3. Redo a picture for the cover. It is cool to put an illustrated cover on your piece when it is finished. You can use color, fill things in, add details, etc. The picture you choose might even suggest a title for our piece.

4. Explore the fine art of caption writing. Captions are short and the student can revise them quickly and easily.

5. Use dialog and thought bubbles. Use dialog bubbles to show people talking. Use thought bubbles to show people thinking."

\section{Definition of Descriptive Paragraph}

Descriptive is constantly describing people, place and object. Description appears in almost writing because writers try hard to create word image of ideas that they convey. There are two elements are crucial for effective description. First, the readers need explicit, specific details if they are created exactly the mental image in their minds. The readers are better able to create exactly the 
mental image if the details appeal to all sense, sight, hearing, taste, touch and smell. Second, the readers need a logical sequence of detail in partial order. The writers describe a person, a place and an object, might work from top to bottom, bottom to top, right to left, clock wise and so on.

Zahrowi, (2009:1-3) states that descriptive text is a text which lists the characteristicthat descriptive text is a texts of something. Description is used in all forms of writing to create a vivid impression of a person, place, object or event, e.g. to; describe a special place and explain why it is special, describe the most important person in your life, and describe the animal's habit in your report. Descriptive writing or text is usually used to help writer develop an aspect of their work, e.g. to create a particular mood, athmosphere or describe a place so that the reader can create vivid pictures of characters, places, object, etc. While in language function, descriptive writing is focused and concentrate only on the aspects that add something to the main purpose of the description-sensory description-what is heard, smelt, felt and tasted. Precise use of adjectives, similes, methapors to create images/pictures in the mind e.g. their noses were met with the acrid smell of rotting flesh. And also strong development of the experience that"put the reader there" focus on key details, powerful verbs and precise nouns. Descriptive writing also consist of generic structure in range as: general statement, explanation and closing.

Pardiyono (2010:29) states that descriptive is to describe a particular person, place or thing. It means you describe their colors, shape, size, weight, height, widht, density, contents and so on. The description has dominant language features as follows: using simple present tense, action verbs, passive voice, noun phrase, adverbial phrase, technical terms and general and abstract noun.

\section{The Generic Structure of Descriptive Paragraph}

According to (Gerrot and Wignel, 1994: 208) state that descriptive text has generic structure as below:

a. Identification (identifies phenomenon to be described) 
In creating a descriptive text, the first thing to do is to make identification. It introduces or identifies the phenomenon to be described. It tells about the name, the address, or the location of the object

b. Description (describes parts, qualities and characteristics).

Description is the second element of the generic structures of descriptive text. It tells about what the phenomenon, introduced in the identification, looks like. It is to say that identification is the opening of the descriptive text, while description is the body of it.

\section{Language Features of Descriptive Text}

According to (Gerrot and Wignel, 1994: 208) state that descriptive text is indicated by specific participant, adjective and compound adjectives, linking verbs, simple present tense, action verbs, and descriptive language as follow:

a. Specific participant; it focuses on specific participant, such as my house and my pet.

b. Adjectives and compound adjectives. For example," a beautiful beach, a handsome man and an adorable cat.

c. Linking verbs. It uses linking verbs such as is, are, has, have, and belongs to.

d. Simple Present Tense. For instance," I have a friend, his name is Samsul".

e. Action verbs. It uses action verbs such as run, sleep, walk, etc.

f. Descriptive language. It uses descriptive language to describe what they look like (color, shape, size, etc), what they have (body parts, components, etc), and what they do (habits, behavior, functions, etc). The language feature of descriptive text is portrayed in the following table: 
Table 3.1The Language Feature of Descriptive Text

\begin{tabular}{|l|l|}
\hline Text & Characteristics \\
\hline \multirow{4}{*}{ Descriptive } & It focuses on specific participant. \\
\cline { 2 - 2 } Paragraph & In describing the features of subject, adjectives are used. \\
\cline { 2 - 2 } & It uses linking verbs (is, are, has, have, belongs to). \\
\cline { 2 - 2 } & A verb used in descriptive text is in form of simple present tense. \\
\cline { 2 - 2 } & It uses action verbs. \\
\cline { 2 - 2 } & It uses descriptive language. \\
\hline
\end{tabular}

Table 3.2 Example of Descriptive Text

\begin{tabular}{|c|c|c|c|}
\hline $\begin{array}{l}\text { Schematic } \\
\text { Structure }\end{array}$ & Title: Spynax & $\begin{array}{l}\text { Linguistic } \\
\text { Features }\end{array}$ & $\begin{array}{l}\text { Oral } \\
\text { Alue }\end{array}$ \\
\hline $\begin{array}{l}\text { General } \\
\text { Statement }\end{array}$ & $\begin{array}{l}\text { Spynax is my cat. He is an } \\
\text { adorable cat. }\end{array}$ & $\begin{array}{l}\text { Specific } \\
\text { Participant }\end{array}$ & \multirow{3}{*}{$\begin{array}{l}\text { oving } \\
\text { animals can } \\
\text { each and remind } \\
\text { the student to } \\
\text { Remember their } \\
\text { creator (God). }\end{array}$} \\
\hline $\begin{array}{l}\text { Description } \\
\text { of appearances }\end{array}$ & $\begin{array}{l}\text { He has orange fur with black } \\
\text { and white spots. I like to } \\
\text { cuddle him because his fur } \\
\text { feels soft. }\end{array}$ & \multirow{2}{*}{$\begin{array}{ll}\text { - } & \text { Present } \\
& \text { Tense } \\
\text { - } & \text { Linking Verb } \\
\text { - } & \text { Action verb } \\
\text { - } & \text { Mental verb } \\
\text { - } & \text { Behavioral } \\
& \text { Verb }\end{array}$} & \\
\hline $\begin{array}{l}\text { Description of } \\
\text { habits and } \\
\text { behavior }\end{array}$ & $\begin{array}{l}\text { Every morning, I give milk. } \\
\text { Spynax doesn't like rice, so I } \\
\text { give him cat food. Spynax is } \\
\text { an active animal. He likes to } \\
\text { run around the house. He likes } \\
\text { to chase everyone in my } \\
\text { house. When he feels tired or } \\
\text { sleepy, Spynax usually sleeps } \\
\text { on the sofa in the living room } \\
\text { or under the table. }\end{array}$ & & \\
\hline
\end{tabular}

\section{RESEARCH METHOLOGY}

This research used a Classroom Action Research (CAR) it was stages those were: Planning, Action, Observation, and Reflection. The researcher held around two cycles and each cycle consisted of four meetings. The first and second cycle; each cycle was the series of activityy which has close relation. Where, the realization of the second cycle was continuing and repairing from the first cycle described as follows:

\section{A. Subject of Research}

Research subject of this classroom action research were the Eighth Grade students of MTs. Muhammadiyah Tongko. This class consisted of 13 men and 17 women. 


\section{B. Research Instrument}

In this research, the researcher used some instrument. They were test and observation sheet. It used to observe and record the students' activities during the teaching and learning process for each cycle.Writing test was designed to measure the students' ability in English writing in each cycle. The test was given to the students as diagnostic test for getting focus of the problem before the cycle of CAR was applied, test in each cycle, after applying the action as evaluation test.

\section{Technique of Collecting Data}

To collect the data, the researcher used observation sheet to find out the students' participant in teaching learning process through DLC technique. It was done in every cycle. It was summed at the end of cycle I and II. The researcher gave test to the students to find out their improvement of students in writing descriptive paragraph by using DLC Technique.

\section{Technique of Data Analysis}

There were two components that concerns of the researcher in this research to measure. Those were content and language use which used criteria as follows:

a. Content

1) Unity

\begin{tabular}{|c|c|c|}
\hline \multirow{2}{*}{ Classification } & \multirow{2}{*}{ Score } & Indicators \\
\hline & & Unity \\
\hline Very Good & 5 & $\begin{array}{l}\text { - } \text { Every sentence develops one central idea. } \\
\text { - Shows a clear understanding of main idea } \\
\text { development }\end{array}$ \\
\hline Good & 4 & $\begin{array}{l}\text { - Some sentences develops one central idea. } \\
\text { - Shows a good understanding of main idea } \\
\text { development. }\end{array}$ \\
\hline Average & 3 & - $\quad$ Some sentences are unrelated with the topic. \\
\hline Poor & 2 & - $\quad$ Less understanding of main development. \\
\hline Very Poor & 1 & $\begin{array}{l}\text { - Most os sentences are unrelated with the topic } \\
\text { - Main idea development is unclear }\end{array}$ \\
\hline
\end{tabular}

2) Completeness

\begin{tabular}{|c|c|c|}
\hline \multirow{2}{*}{ Classification } & \multirow{2}{*}{ Score } & Indicators \\
\hline & & Completeness \\
\hline Very Good & 5 & $\begin{array}{l}\text { - } \quad \text { Providing information very well. } \\
\text { - } \quad \text { Main idea has been developed in full completeness. }\end{array}$ \\
\hline Good & 4 & $\begin{array}{l}\text { - } \quad \text { Providing information well enough } \\
\text { - } \quad \text { Main idea has been developed completely }\end{array}$ \\
\hline Average & 3 & $\begin{array}{l}\text { - } \quad \text { Lack of providing information. } \\
\text { - } \quad \text { Main idea has been developed completely }\end{array}$ \\
\hline
\end{tabular}




\begin{tabular}{|l|l|ll|}
\hline Poor & 2 & $\bullet$ & Main idea has been develop rather complete \\
\hline Very Poor & 1 & $\begin{array}{l}\bullet \\
\bullet\end{array}$ & $\begin{array}{l}\text { No providing information } \\
\text { Uncomplete main idea's development }\end{array}$ \\
\hline
\end{tabular}

b. Language Use

Tenses and preposition

\begin{tabular}{|l|l|l|}
\hline Classification & Score & Criteria \\
\hline Very Good & 5 & $\begin{array}{l}\text { If the paragraph are all correct of the } \\
\text { grammar,present tense, preposition }\end{array}$ \\
\hline Good & 4 & $\begin{array}{l}\text { If the paragraph contain few errors of the } \\
\text { grammar present tense, preposition }\end{array}$ \\
\hline Everage & 3 & $\begin{array}{l}\text { If the grammar contain some errors of the } \\
\text { grammar presenttense,preposition }\end{array}$ \\
\hline Poor & 2 & $\begin{array}{l}\text { If the paragraph contain are dominated by errors } \\
\text { of the grammar present tense,preposition }\end{array}$ \\
\hline Very Poor & 1 & If the paragraph are all incorect. \\
\hline
\end{tabular}

\section{Data Analysis}

The data analysis in the classroom action research from the test will be analyzed with:

1. Scoring students' answer of the students' writing ability, the researcher will used percentage technique

The Corerrect Answer

Scoring= x 100

Maximum Score

(Sudjana,1990)

2. To find out the mean score of the students'achievement in writing descriptive paragraph through DLC Technique by using the following formula:

$$
\bar{X}=\frac{\Sigma X}{N}
$$

Where: $\quad \bar{X}=$ The Mean Score

$\Sigma X=$ The Sum of All Score

$\mathrm{N}=$ The Total Number of the Student

(Gay, 1981:298)

3. To know the improvement of the students' writing ability the researcher 
used percentage technique by using this formula:
( D- Test
C I) $\mathrm{P}=\frac{X 1-(D-\text { Test })}{D-\text { Test }} \times 100$
( C I
$\longrightarrow$ C II) $\mathrm{P}=\frac{X 2-X 1}{X 1} \times 100$
( D-Test
C II) $\mathrm{P}=\frac{X 2-D-T e s t}{D-T e s t} \times 100$

\section{Where:}

P: Percentage of the students

X1: First Cycle

$\mathrm{X} 2$ : Second Cycle

D- Test : Diagnostic Test

(Sudjana, 1999).

4. To analiyzed the students' participation in research toward the material and activities in teaching and learning process by checklist. The students' active participation described followed:

\begin{tabular}{|l|l|l|l|}
\hline No & $\begin{array}{l}\text { The students' Active } \\
\text { Participation }\end{array}$ & Score & Indicators \\
\hline 1. & Very active & 4 & $\begin{array}{l}\text { Students' respond to the material very } \\
\text { active }\end{array}$ \\
\hline 2. & Active & 3 & Students' respond to the material actively \\
\hline 3. & Fairly active & 2 & $\begin{array}{l}\text { Students' respond to the material just once } \\
\text { or twice. }\end{array}$ \\
\hline 4. & Not active & 1 & $\begin{array}{l}\text { Students just sit down during the activity } \\
\text { without doing something. }\end{array}$ \\
\hline
\end{tabular}

\section{FINDINGS AND DISCUSSION}

\section{The Implementation of Draw Label Caotion (DLC) Technique}

The researceher conducts planning before the action, where she prepared the lesson plan through implementation of Draw Label Caption Technique, teaching material, and evaluation for students. The activity in action stage for cycle $\mathrm{I}$ is the implementation of the lesson plan. It means that the implementation of every steps of the learning process through Draw Label Caption Technique which have been arranged in the planning stage.

Firstly, the researcher gave stimulation and motivation before the process of teaching writing ability. Secondly, the researcher gave the students the theme that will be the main idea of their writing. Thirdly, the researcher asked the 
students to write descriptive paragraph by draw or made a simple sketch about the theme. Fourhtly, the researcher asked the students to create a label for everything on the pictures. Fifthly, the researcher asked the students to write one sentence caption for their pictures. Sixthly, the researcher asked the students to write descriptions or explained about every label on the pictures. Sevently, the researcher asked the students to make revision for their writing to complete the story. Eightly, the students evaluated the writing done before and after the model to see if more creative insight had been added so that the students might produce a product or description that utilized the ideas generated in the process. If the result of the students' scores do not achieve the target then cycle II will be taken.

The activity in the second cycle is almost same with the first cycle. Where, before taking action, the researcher previously makes planning and implies it in the action stage. The difficulty that the researcher find in the cycle I is the students still difficult to get idea and organize their writing to be a good paragraph.

Descriptive paragraph is about how to describe something and in the writing project, the teacher has chosen a theme that is relative to their environment. Meanwhile, the result of the students' writing is still vague the readers. They do not finish their writing about the themes given.

It can be understood if considering the class situation during the teaching process. Only few of them show their interest in learning and following the teaching process. The others look bored and have no mood in learning process. They are very noise and just playing around the class. It shows that the teaching process during cycle $\mathrm{I}$ is not interesting at all for them. So, the teacher decides to make some revision for the next cycle.

The result of revision planning to resolve the students' difficulty in getting idea is providing some interesting thems for the students' writing project. Besides providing some interesting themes the teacher also reforms many aspects such as more relaxed in teaching, gives the students motivation before entering the main learning material, explains the learning material clearly, raises the voice, and recorrects the class management, and time management. The teacher also gives the 
students chance to ask the question, explains the students' mistakes in writing clearly and guided the students in writing well.

Besides, the result of their writing is also influenced by their mood and interest to the theme specifically and the writing lesson generally. She finds also that the students can be more understand about the space of paragraph, for example: the descriptive paragraph of " a beautiful person", the students explained about the theme. That theme is related with their shelf and the researcher can see how interested they are in doing their writing project. Finally, the students' mean score can achieve the target of score. The teacher concludes that the students' writing mean score based on the elements of content and language use that the target that has been said in the chapter I could be achieved.

The results of the findings indicate that Draw Label Caption (DLC) Technique can improve the students' writing ability to write descriptive paragraph viewed from its conten and language use. Further interpretations of the data analysis are given below:

\section{The Students Improvement in Content}

The improvement of the students' writing descriptive paragraph, based on content aspect, which focused on unity and completeness as indicator by using Draw Label Caption Technique in MTs. Muhammadiyah Tongko as result of the students' assessment of cycle I and cycle II described as follows:.

Table 1: The students' Improvement of Content

\begin{tabular}{|c|c|c|c|c|}
\hline \multirow[t]{2}{*}{ No. } & \multirow[t]{2}{*}{ Indicators } & C- I & C- II & $\begin{array}{c}\text { Improvement } \\
(\%)\end{array}$ \\
\hline & & Score & Score & CI-CII \\
\hline 1. & Unity & 66.66 & 78.66 & 12 \\
\hline 2. & Completeness & 63.33 & 76.66 & 13.33 \\
\hline & & 129.99 & 155.32 & 25.33 \\
\hline & $\bar{X}$ & 64.99 & 77.66 & 12.66 \\
\hline
\end{tabular}

The data in the table above show the students' writing ability in content as the result of calculating of the diagnostic test and students' test at the students' writing by using Draw Label Caption (DLC) Technique. Where the students score in diagnostic test is different from the students' test in the first cycle. The mean 
score in the first cycle is 64.99 and in cycle II is 77.66. The assessment of the second cycle is greater than the first cycle $(77.66 \%>64.99)$ and classified as good. And then, improvement from the first cycle to the second cycle is $12.66 \%$.

Based on the percentages above there are significant improvements of the students in writing descriptive paragraph through (DLC) Technique.

\section{The Students' Improvement in Language Use}

The improvement of the students' writing descriptive paragraph, based on language use aspect, which focused on tense and preposition as indicator by using Draw Label Caption Technique in MTs. Muhammadiyah Tongko as result of the students' assessment of cycle I and cycle II described as follows:.

Table 2: The students' Improvement of Language Use

\begin{tabular}{|l|l|c|c|c|}
\hline \multirow{2}{*}{ No. } & \multirow{2}{*}{ Indicators } & C- I & C- II & $\begin{array}{c}\text { Improvement } \\
(\mathbf{\%})\end{array}$ \\
\cline { 3 - 5 } & Score & Score & CI-CII \\
\hline 1. & Tense & 64.66 & 74.66 & 10 \\
\hline 2. & Preposition & 61.33 & 72 & 10.67 \\
\hline \multicolumn{2}{|c|}{$\sum X$} & $\mathbf{1 2 5 . 9 9}$ & $\mathbf{1 4 6 . 6 6}$ & $\mathbf{2 0 . 6 7}$ \\
\hline \multicolumn{1}{|c|}{$\bar{X}$} & $\mathbf{6 2 , 9 9}$ & $\mathbf{7 3 , 3 3}$ & $\mathbf{1 0 . 3 3}$ \\
\hline
\end{tabular}

The data in the table above show the students' writing ability in language use as the result of calculating of the first cycle and the second cycle at the students' writing by using Draw Label Caption (DLC) Technique, where the students' score in the first cycle and the second cycle is different. The mean score in the first cycle is 62.99, and the second cycle is 73.33. The achievement of the second cycle is greater than the first cycle $(73.33>62.99)$ and classified as good. And then, improvement from the first cycle to the second cycle is $10.33 \%$.

Based on the percentages above there is a significant improvements of the students by using DLCTechnique .

3. The improvement of the students' writing descriptive Paragraph through Draw Label Caption (DLC) Technique 
The implementation of Draw Label Caption (DLC) Technique in improving the students' writing covered content and language use. The improvement of the students' writing can be seen clearly in the following table:

Table 3: The Students' Improvement in Writing Descriptive Paragraph

\begin{tabular}{|l|l|l|l|l|}
\hline \multirow{2}{*}{ No. } & \multirow{2}{*}{ Indicators } & C- I & C- II & $\begin{array}{c}\text { Improvement } \\
(\mathbf{\%})\end{array}$ \\
\cline { 3 - 5 } & & Score & Score & CI-CII \\
\hline 1. & Content & 64.99 & 77.66 & 12.66 \\
\hline 2. & Language Use & 62.99 & 73.33 & 10.33 \\
\hline & $\sum X$ & $\mathbf{1 2 7 . 9 9}$ & $\mathbf{1 5 0 . 9 9}$ & $\mathbf{2 2 . 9 9}$ \\
\hline & $\bar{X}$ & $\mathbf{6 3 . 9 9}$ & $\mathbf{7 5 . 5 0}$ & $\mathbf{1 1 . 4 9}$ \\
\hline
\end{tabular}

The table above indicates that there is improvement of the students' writing descriptive paragraph from the first cycle and the second cycle is different. After evaluation in the first cycle the students' writing becomes (63.99) and categorized as fair and the second cycle (75.50) which categorized as good. The improvement of students' writing ability achieve from the first cycle to the second cycle (11.49). There is also significant improvement of the students' writing ability from the first cycle to the second cycle.

The table above proves that use of DLC Technique in teaching and learning process is able to improve the students' writing ability after taking action in the first cycle and the second where the students' achievement in the second cycle is greater than the first cycle.

\section{Observation Result of Students' Activeness in Learning Process}

The result of observation of the students' activeness in teaching and learning process toward the application of Synectics Method in improving the students' writing ability at the eighth year students of MTs. Muhammadiyah Tongko in class VIII-2 which is conducted in 2 cyles during 8 meeting is taken by the observer through observation sheet. It can be seen clearly through the following table: 
Table 4: The Percentage of the Students' Activeness

\begin{tabular}{|c|c|c|c|c|c|}
\hline \multirow{2}{*}{ Cycle } & \multicolumn{4}{|c|}{ Meetings } & $\begin{array}{c}\text { Average } \\
\text { Score }\end{array}$ \\
\cline { 2 - 5 } & I & II & III & IV & \\
\hline I & $57.5 \%$ & $63.33 \%$ & $71.66 \%$ & $74.16 \%$ & $66.66 \%$ \\
\hline II & $76.66 \%$ & $77.5 \%$ & $78.33 \%$ & $80 \%$ & $78.12 \%$ \\
\hline
\end{tabular}

Based on the table above, the researcher can explain that the students' observation in learning writing through Draw Label Caption Technique in cycle I increase with percentage of first meeting until fourth meeting 57,7\%, 63,33\%, $71.66 \%, 74.16 \%$ with the mean score $66.66 \%$. The percentage of the first meeting until fourth meeting of cycle II are $76.66 \%, 77.5 \%, 78.33 \%, 80 \%$ with the mean score $78.12 \%$. It means that the students' observation shows process from cycle I to cyle II. The improvement of students' activeness is $15 \%$. The data is also shown in the graphic below:

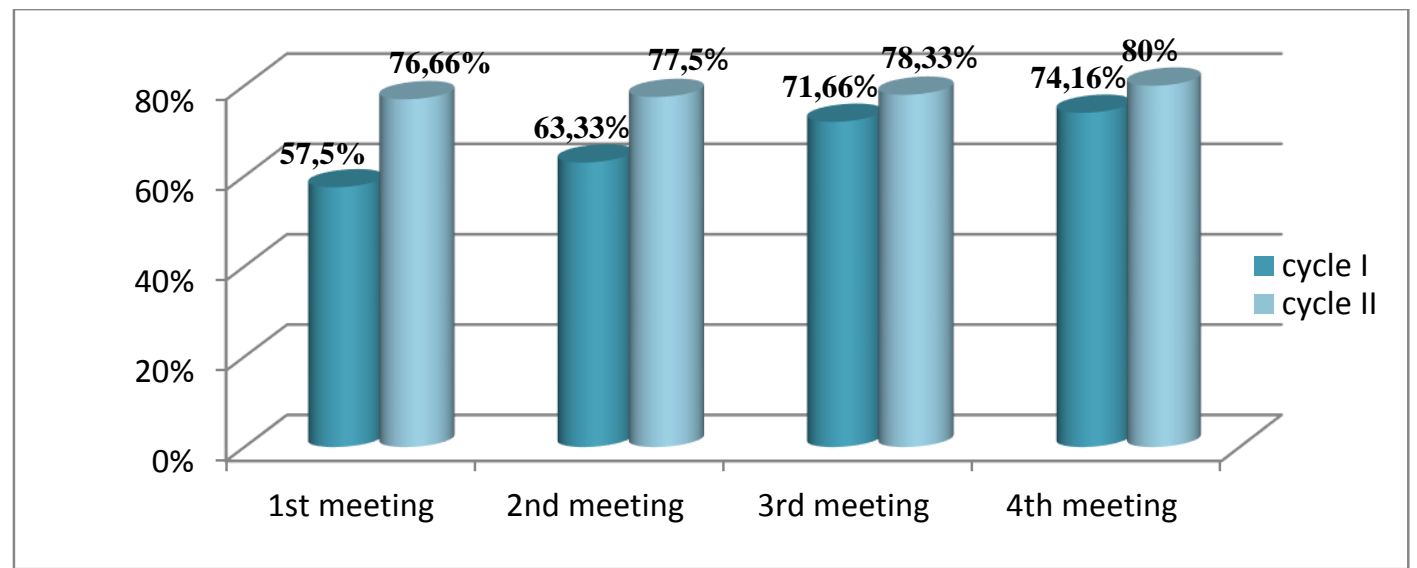

Figure : The Percentage of the Students' Activeness in Learning Process

The chart above shows the students' observation in learning writing through Draw Label Caption Technique in the students of MTs. Muhammadiyah Tongko in class VIII-2. This graphic presents the students situation during teaching learning process in writing from cycle I to cycle II. From the graphic it is known that there is the changing of the students' situation in learning process from cycle I to cycle II. The students' participation in learning process is improved with the mean score $66,66 \%$ and than $78,12 \%$. There is improvement of students' activeness in teaching and learning process where in cycle I is $66,66 \%$ 
lower than cycle II is $78,12 \%$. It means that (Cycle II > Cycle I). The improvement of students' activeness is $15 \%$.

\section{A. DISCUSSION}

Based on the problem statements, the researcher answered question in problem statements. DLC Technique can improve of conten and language use in writing ability at descriptive paragraph. The programming of DLC Technique is concerned with training ourselves to think and imagine, gathering information about their internal and external views. Related with objective of the study, the students' of MTs. Muhammadiyah Tongko can improve writing ability through DLC Technique for measured in connection with content, should be unity and completeness in writing involves unity and completeness. The parts element of writing as follow:

\section{The Implementation of Draw Label Caption Technique}

The researcher observed many aspects to asses the implementation of DLC technique such as; students' attitude, students' model and students' understanding. The students show their progress in every meeting. The First, students' attitude. In this aspect researcher observes the respond of the students. In the first meeting students' respond is very low, but in the cycle II the students' respond classified into good. Secondly, students' model in teaching and learning process. In this case, researcher observes students' behavior during learning and teaching process. In the first meeting students' behavior is very low but in the cycle II the students' behavior classified into good, this aspect almost same with the students' attitude aspect. And the third aspect is students' understanding. In the first cycle students' understanding is fair but after doing cycle II the students' understanding is good.

Most of Students' interest to study and they are not feel bored in learning through this Technique. The students' writing ability can be improved through DLC technique, because by this technique, they can express their ideas freely with their own scene in their mind before and helps the students to find words more, so that it make easy for the students to arrange their idea into a good 
descriptive paragraph. This technique is so fun and interesting not only for the students which enjoy to express their ideas as they wish but also helps the readers to create the same picture in their minds and know the purpose of their writing directly without read the paragraph.

\section{The Improvement of the Students' in Writing Component of Content.}

The improvement of the students' ability to write good paragraphs after implementing DLC Technique had effect that was effective. Where, the researcher found in the data source from D-Test result in component of content that the students just could get score that was 53.66, it means that it was far from the target, but after implementing the students could get score 64.99 in the cycle I and in cycle II it became 77.66 .

The researcher taught about the descriptive paragraph in the cycle 1 through DLC Technique in the class. The researcher found that the students still difficult to write well, especially to used appropriate unity and completeness. The difficulty of the students in content had been analyzed, so the researcher had to think the solution of the problem. So, the researcher decided to do the cycle 2 by doing revision in the lesson plan which prepared in revision planning of cycle 2.

The value improvement of the students' writing achievement in content from D-Test to cycle I and also from cycle I to cycle II (Diagnostic-Test $(53.66) \leq$ Cycle I (64.99) $\leq$ Cycle II (77.66), where in D-Test the students' mean score in content is 53.66 after evaluation in cycle I the students' mean score achievement in content becomes 64.99, so the improvement of students' writing achievement in content from D-Test to cycle I is 11.33 .

While in cycle II the students' mean score in content is 77.66. So, the improvement of students' mean score achievement in content from cycle I to cycle II is 12.66 From the result of those tests namely from D-test to cycle II indicates that there is a significant improvement of students' mean score achievement in content from D-test to cycle II namely 23.99.

The result above also proves that DLC Technique was able to improve the students' writing achievement significantly. It seen clearly the result of cycle II 
(77.66) is higher than cycle I (64.99) and D-test (53.66) or cycle II (77.66) $\geq$ cycle I (64.99) $\geq$ D-test (53.66).

\section{The Improvement of the Students' Achievement in Writing Component of}

\section{Language Use}

After implementation of DLC Technique in the class, the researcher found that the mean score of data source from D-Test in language use was 48.33. In the cycle I the students got 62,99 and in the cycle II the students got 73.33.

The researcher taught about the descriptive paragraph in the cycle 1 through implementation of DLC Technique in the class. The researcher found that the students had difficulty to content the idea. The students have less skill in content element of writing.

Based on the unsuccessful teaching in the cycle I, the researcher decided to do cycle II. In the cycle II, the researcher revised the lesson plan. Where, when the researcher explained about the descriptive paragraph and the kinds of generic structure of descriptive paragraph the researcher should explain more clearly, if needed gave the students occasion to ask about the material. Besides that, the researcher had to give better guidance for the student in content their idea.

The value improvement of the students' writing achievement in language from D-Test to cycle I and also from cycle I to cycle II (Diagnostic-Test $(48.33) \leq$ Cycle I $(62,99) \leq$ Cycle II $(73,33)$, where in D-Test the students' mean score in language use is 48.33, after evaluation in cycle I the students' mean score achievement in language use becomes 62.99, so the improvement of students' writing achievement in language use from D-Test to cycle I is 14.66.

While in cycle II the students' mean score in language use is 73.33. So, the improvement of students' mean score achievement in language use from cycle I to cycle II is 10.17 From the result of those tests namely from D-test to cycle II indicates that there is a significant improvement of students' mean score achievement in language use from D-test to cycle II namely 25.

The result above also proves that DLC Technique is able to improve the students' writing achievement significantly. It seen clearly the result of cycle II 
(73.33) is higher than cycle I (62.99) and D-test (48.33) or cycle II (73.33) $\geq$ cycle I (62.99) $\geq$ D-test (48.33).

\section{The Improvement of The Students' Achievement in Writing Result}

The effectiveness of Drwa Label Caption Technique in improving the students' achievement writing result can be seen the difference by considering the result of the students' Diagnostic Test, cycle I and cycle II.

The value improvement of the students' achievement writing result from D-Test to cycle I and also from cycle I to cycle II (Diagnostic-Test (50.99) $\leq$ Cycle I (63.99) $\leq$ Cycle II (75.50), where in D-Test the students' mean score in writing result is 50.99, after evaluation in cycle I the students' mean score achievement in writing result becomes 63.99, so the improvement of students' writing achievement in writing result from D-Test to cycle I is 13 . While in cycle II the students' mean score in writing result is 75.50. So, the improvement of students' mean score achievement in writing result from cycle I to cycle II is 11.51 and from the result of those tests namely from D-test to cycle II indicates that there is a significant improvement of students' mean score achievement in writing result from D-test to cycle II namely 24.51 . The result above also proves that DLC Technique was able to improve the students' writing achievement in writing result significantly. It seen clearly the result of cycle II (75.50) is higher than cycle I (63.99) and D-test (50.99) or cycle II (75.50) $\geq$ cycle I (63.99) $\geq$ Dtest (50.99).

\section{The Improvement of the Students' Activeness During the Teaching and Learning Process}

The observation result of the students' activeness in teaching and learning process improved significantly through Draw Label Caption Technique in cycle I the students' activeness in the $1^{\text {st }}$ meeting is $57,5 \%$ its mean that there is still the other activity that the students' were done during the teaching and learning process. Next meeting researcher repair the weakness so the activeness of students in last meeting of cycle I become $75 \%$. the in the cycle II the researcher gave 
revision again for problem that students faced during the teaching and learning process so in cycle II, the students' activeness in the last meeting become $80 \%$. Its mean that the students pay full attention during teaching and learning process and there is no another activity that the students were done. The students are joining the teaching and learning process seriously. Even if some students did not know what they would write yet they were still active in asking. It means that, the application of Draw Label Caption Technique could improve the students' activeness during teaching and learning process and it is successful.

Base on the interpretation on the findings above, indicate that there is a significant improvement of the students activeness during teaching and learning process from the first meeting in cycle I until the last meeting in cycle II in Class VIII-2 of MTs.Muhammadiyah Tongko.

\section{CONCLUSION AND SUGGESTION}

\section{A. Conclusion}

Based on the findings and discussion in the previous chapter, the researcher inferential in the following conclusion.

1. DLC technique was one of a good technique in writing descriptive paragraph. It showed from the students' ability to write descriptive paragraph viewed from its content of diagnostic test is 53.66, in cycle I was 64.99, and cycle II was 77.66. The students' progress from the diagnostic test to the cycle I is $11.33 \%$, the cycle I to the cycle II is $12.66 \%$, and diagnostic test to cycle II is $23.99 \%$

2. Meanwhile, the students' ability viewed from its language use of diagnostic test is 48.33 the cycle I is 62.99 and cycle II is 73.33 The students' progress from the diagnostic test to the cycle I is $14.66 \%$, the cycle I to the cycle II is $10.17 \%$. and diagnostic test to cycle II is $25 \%$.

3. DLC technique can improve the students' activeness in learning English process especially in learning writing subject. By working with DLC technique makes the students active and stimulates their thought to write down whatever comes in mind in producing descriptive paragraph. It is proved through the 
teacher observation of the students' activeness in learning process with significant improvement in cycle I $(68.12 \%)$ and in cycle II $(78.53 \%)$.

\section{B. Suggestion}

Based on the findings, the writer stated suggestions as follows:

1. It is suggested that the English teachers apply DLC technique as one of the alternative ways in teaching writing skills.

2. The students are expected to increase their intensity in learning writing through DLC technique.

3. It is suggested to the English teachers that they maximize in giving guidance to the students in learning and teaching writing process.

4. The researcher conducts similar researches for getting better result of the research, so that the students get increase in their learning.

\section{REFERENCES}

Agoestiowati, Redjeki. 2010. Fun English Game and Activities for You. Jakarta: PT. Buana Ilmu Populer.

Brereton. 1982. A Plan for Writing Skills. New York: CBS College Publishing.

Bull, Victoria. 2008. Oxford Learner's Pocket Dictionary Fourth Edition. New York: Oxford University Press.

Bumgarden, Julie. 28 Mei 2010. Summary of Using Draw Label Caption Technique in Writing. Teaching That Make Sense Discussion, (online), http://www.ttms.com. Retrieved on 25 Juni 2012.

Byrne, Donn. 1995. Teaching Writing Skills. London and New York: Longman Group UK Limited.

Byrne, Donn. 1988. Teaching Writing Skills. London: Longman.

Couch, Richard. 1993. Synectics and Imagery: Developing Creative Thinking through Images. In: Art, Science \& Visual Literacy: Selected Readings from the Annual Conference of the International Visual Literacy Association (24th, Pittsburgh, PA. September 30 - October 4, 1992). (ERIC Document Reproduction Service No. ED 363 330). 
Depdikbud, 2003. Garis - GSaris Besar Program Pelajaran Mata Pelajaran Bahasa Inggris Kurikulum Sekolah Menengah Umum. Dirjen Dikdasman.

Descriptive. 2009. Online (http://ardictionary.com/descriptive/3418). Accessed on June $12^{\text {nd }} 2012$.

Ferrance, Eilleen. 2000. Action Research. New York: Brown University.

Gay, L. R. 1981. Education Research. New York: Prentice Hill

Gerrot, L. and Wignel, P. 1994. Making Sense of Functional Grammar. New South Wales: Antipodean Educational Enterprises (AEE).

Harmer, Jeremy. 1991. The Practice of English Language Teaching. New York:Longman.

Heard James, M.Ed. \& Ted Tucker, M. Ed. 2000. Advanced Writing. An advanced Writing Course Designed Specifically for The Needs of Korean University Students.

Heaton, J.B. 1984. Writing English Language Test. Singapore: Banwash Press Ptc., Ltd.

Jacobs, Holly L. et al. 1981. Testing ESL Composition: A Practical Approach. London: Newbury House Publisher,Inc.

Laksana, A. S. 2005. Creative Writing. Jakarta: Mediakita.

Muslich, 2009. Melaksanakan PTK itu Mudah. Jakarta: PT. Bumi Aksara.

Oshima, Alice and Ann Hogue.2006. Writing Academic English. New York: Longman.

Peha, Steve. 2002.What is Good Writing. Teaching That Make Sense.: 3

Peha, Steve. 2003. The Writing Teacher Strategy Guide. Teaching that Make Sense: $47-51$.

Pardiyono. 2010. The Art of Teaching. Yogyakarta: Andi Yogyakarta.

Steve. 2002. Teaching That Makes Sense. www.ttms.org

Sudjana.1999.Metode Statistika.Bandung: PT Gramedia

Taylor, Gordon. 2009. A Students' Writing Guide. How to Plan and Write Succesful Essay. New York: Cambridge University Press.

Tenri A,A. Hj. 2012. Penelitian Tindakan Kelas. Makassar: seminar 
Walton. 2007. Draw Label Caption. English Advantage, (online). http:// www.englishadvantage.info/lesson-plans/draw-label-caption, retrieved on 25 Juni 2012.

Yakkop, 2006. Cooperative Learning in Improving Writing Skill at SMU Nasional Makassar. Unpublished Thesis. Makassar: Universitas Muhammadiyah Makassar. 